DOI: https://doi.org/10.24127/ajpm.v9i1.2589

\title{
THE SELF REGULATED LEARNING, HABIT OF MIND, AND CREATIVITY AS HIGH ORDER THINKING SKILLS PREDICTORS
}

\author{
H. Hodiyanto ${ }^{1)}$ Muhamad Firdaus ${ }^{2)}$ \\ ${ }^{1,2}$ Pendidikan Matematika, IKIP PGRI Pontianak, Indonesia \\ E-mail: $\quad$ hodiyanto@ikippgriptk.ac.id ${ }^{1)}$ \\ kiranafirdiani@gmail.com $^{2)}$
}

Received 05 January 2020; Received in revised form 25 March 2020; Accepted 29 March 2020

\begin{abstract}
The purpose of this research was to show that self regulated learning, habit of mind, and creativity could be used as predictors of high order thinking skills (HOTS). This research used quantitative method, ex post facto research. Data collection techniques used measurement and indirect communication techniques and data collection tool that used was HOTS test and questionnaire. The population were all undergraduate students of the first semester of mathematics education study program IKIP PGRI Pontianak. The sample of this research was taken by using the random cluster sampling technique and one class was obtained as a research sample with 30 students. Data analysis techniques in this study used inferential statistics, multiple regression. Based on the result of research, it was found that: self regulated learning could be a predictor of HOTS, habits of mind could be predictor of HOTS, creativity could be predictor of HOTS, and self regulated learning, habit of mind, and creativity simultaneously could be used as predictors of HOTS. The results of this study also indicated that the influence of HOTS was not only the model or learning strategy used but there were other variables like self regulated learning, habit of mind, and creativity.
\end{abstract}

Keywords: Creativity; Habit of Mind; HOTS; Self Regulated Learning; Soft Skill.

\begin{abstract}
Abstrak
Tujuan penelitian ini adalah untuk menunjukkan bahwa kemandirian belajar, kebiasaan berpikir, dan kreativitas dapat dijadikan sebagai prediktor terhadap kemampuan berpikir tingkat tinggi. Metode penelitian ini menggunakan metode kuantitatif dengan bentuk penelitiannya berupa penelitian ex post facto. Teknik pengumpulan data yang digunakan adalah teknik pengukuran dan komunikasi tidak langsung sehingga alat pengumpul data yang digunakan adalah tes HOTS dan angket. Populasi dalam penelitian ini adalah seluruh mahasiswa semester I program studi pendidikan matematika IKIP PGRI Pontianak. Teknik pengambilan sampel menggunakan teknik cluster random sampling dan diperoleh satu kelas sebagai sampel penelitian dengan jumlah mahasiswa sebanyak 30 orang. Teknik analisis data dalam penelitian ini menggunakan statistik inferensial, regresi berganda. Hasil penelitian menunjukkan bahwa: kemandirian belajar dapat dijadikan prediktor terhadap HOTS, kebiasaan berpikir dapat dijadikan prediktor terhadap HOTS, kreativitas dapat dijadikan prediktor terhadap HOTS, dan kemandirian belajar, kebiasaan berpikir, dan kreativitas secara simultan dapat dijadikan sebagai prediktor terhadap HOTS. Selain itu, hasil penelitian ini juga menunjukkan bahwa yang dapat mempengaruhi HOTS tidak hanya model atau strategi pembelajaran saja, tetapi ada variabel lain yang bisa berpengaruh terhadap HOTS seperti kemandirian belajar, kebiasaan berpikir, dan kreativitas.
\end{abstract}

Kata kunci: kebiasaan berpikir; kemandirian belajar; keterampilan; kreativitas; kemampuan berpikir tingkat tinggi.

\section{INTRODUCTION}

The skills of mathematical problem solving and communication are one of the high order thinking skills (HOTS). According to Lambertus, et al. (2014), mathematical problem solving skill is a very important high-level thinking process. The problem-solving skill is an attempt to find a solution of a goal that is not easy to be resolved immediately (Polya, 1973). The problem solving is often challenging 
because students do not directly know the solution process $(\mathrm{Yu}$, Fan \& Lin, 2015). Thus, in problem solving, the problem cannot be solved directly by students but they need to understand and associate the problem with previous subject or problems done, so that in solving the problem students must think hard. Problem solving indicators consist of: understanding the problem, devising a plan, carrying out the plan (solve the problem according to plan), and looking back (Polya, 1973).

The skill of mathematical communication is the ability to express ideas, describe, and discuss mathematical concepts coherently and clearly (Lomibao, Luna \& Namoco, 2016). According to Prayitno, Suwarsono, \& Siswono (2013) mathematical communication is a way of student to express and interpret mathematical ideas both orally and in writing, either in drawings, tables, diagrams, formulas, or demonstrations. It can be concluded that to reveal the skill of mathematical communication can be seen from oral and written communication. The communication skills in this research is the mathematical communication skill on the aspects of writing. Indicators of mathematical communication skill in this research are: (1) written text, explaining idea or solution of a problem or drawing by using own language, (2) drawing, explaining idea or solution from mathematical problem in drawing form, and (3) mathematical expression, expressing problems or everyday events in the mathematical language (Hodiyanto, 2017a).

Further in this study, HOTS or higher-order thinking skills are terms used for mathematical problem-solving skill and mathematical communication skill. Based on the findings indicate that
Students' inability in answering the HOTS problems (Pearce, Bruun, Skinner, \& Mohler, 2013; Salemeh, \& Etchells, 2016; Hodiyanto, 2017b; Abdullah, Abidin \& Ali, 2015). Indonesia for Program for International Student Assessment (PISA) in 2015 result shows that Indonesian students' math scores are in 63 out of 70 participating countries and Trends in International Mathematics and Science Study (TIMSS) 2011, Indonesian students are in 38th position from 42 participating countries. One of the causes of low PISA and TIMSS results is the students' inability in solving HOTS problems tested in PISA and TIMSS.

Students' inability in solving HOTS problems are certainly caused by many factors. Some factors that cause them include: (1) model, strategy, or approach applied is not maximal and is not in accordance with the material to be taught, (2) teacher is less attention to student soft skills, (3) inadequate facilities at school, (4) lack of human resources of teacher. There are other factors that cause Students' inability in solving HOTS problems. In many studies, many researchers try to develop and improve student HOTS by applying an innovative learning model in improving HOTS as conducted by Pawiro, Budiyono, \& Slamet (2015), and Hodiyanto, Budiyono, \& Slamet (2016). The researchers before have never researched and predicted HOTS from students' soft skills, even though soft skills can be used as predictions and certainly can also affect HOTS. They also didn't see the effect of soft skills (self regulated learning and habit of mind) simultaneously to the HOTS. Therefore, in this study, researchers want to pay attention to the soft skills of students to HOTS. 
DOI: https://doi.org/10.24127/ajpm.v9i1.2589

Soft skills are interpersonal skills (person skills when dealing with others) and intrapersonal skills that are able to develop maximum performance (Hendrian, Rohaeti, \& Sumarmo, 2017). One of soft skills are self regulated learning and habit of mind (Hendrian, et al., 2017 and Sumarmo, 2015). Self regulated learning is a key concept of success in academic special learning outcomes and currently many studies that illustrate how it relates to the success of learning in educational studies (Fadlelmula, 2010). Selfregulated learning is defined as a student's readiness in organizing and controlling his learning activities on the basis of considerations, decisions and is responsible for his learning activities (Novilita \& Suharnan, 2013).

Self regulated learning and habit of mind are important factors of individual circumstances that influence learning (high order thinking) (Hendrian, et al., 2017). The habit of mind is an essential mathematical disposition that needs to be possessed and developed especially for students who studies high order thinking skills (HOTS) (Hendrian, et al., 2017). This means that in solving the problem of HOTS, the students must understand mathematical content and they must also have a good habit of mathematical thinking and want to interact with others. Students having a good self regulated learning are usually more enthusiastic in learning and never give up so they will be easier to solve HOTS problems. Likewise, students having a good habit of mind, they are used to solving problems and looking for new ideas in solving problems so that it will be easier to solve HOTS problems.

Creativity is the ability of a person to create something new (idea or work) and is relatively different from what has been there before both with respect to the science, humanities, or other arts (Muqodas, 2015). From this understanding then students having high creativity then will have many ideas in solving problems and able to find new ideas in solving the problem so that the better creativity of students then the learning outcomes will be higher. Various studies have shown that creativity influences student learning outcomes (HOTS), such as Naderi \& Abdullah (2010) and Hodiyanto et al. (2016). In this study, researchers want to show that the self regulated learning, habits of mind, and creativity can be predicted on the development and improvement of college student HOTS. Therefore, the purpose of this study is to show: the self regulated learning, habit of mind, and creativity can be used as predictors of HOTS, and the self regulated learning, habit of mind, and creativity can be used simultaneously as predictors of HOTS.

\section{RESEARCH METHOD}

The research method used in this research is quantitative research. The form of quantitative research in this study is ex post facto research. The research of cause and effect is carried out on programs, activities or events that have taken place or have occurred. In this research, besides the researchers want to show the influence of the self regulated learning, habit of mind, and creativity partially to HOTS, the researchers also want to show that the self regulated learning, habit of mind, and creativity simultaneously can be predicted to the student HOTS development. Therefore, the variables used in this study consist of two variables, the dependent variable (HOTS) (Y) and the three independent variables: the self regulated learning 
(X1), habit of mind (X2), and creativity (X3). Data analysis is performed after the prerequisite analysis test is met. If the criteria on the prerequisite analysis test are met then proceed with multiple regression analysis.

Population in this research are all undergraduate students of first semester of Mathematic Education Study Program of IKIP PGRI Pontianak West Kalimantan Indonesai consisting of four classes that are A and B class in morning and afternoon. The sampling technique in this research uses cluster random sampling technique. Before the samples are taken first, the homogeneity test is done to see whether the population is homogeneous or not. Data used in this homogeneity test is the student UTS results of the first semester. Based on homogeneity test results using barlett test, it is found that the students are in the same or homogeneous. Furthermore, in a random way is taken one class to be sampled, so B class student in morning of the first semester is as a sample of research.

Data collection techniques used depend on what data required in the research. Data collecting techniques in this study use measurement techniques and indirect communication. The result of this measurement is quantitative data. s on the data collecting technique used. The data collection tools used in this study are test and questionnaire.

The test used in this study is essay tests for high order thinking skills (HOTS) consisting of the mathematical problem solving and communication skills. The indicators of Mathematical communication skills are written text, drawing, and matematical ekpression, while indicators of problem solving skills: understanding the problem, devising a plan, carrying out the plan, and looking back.

Questionnaires used in this study are questionnaire for self regulated learning, habit of mind, and creativity. The Indicators of self regulated learning are environment structuring, goal setting, time management, help seeking, task strategis, and self evaluation. Indicators of the habit of mind are enduring or never giving up, managing conscience, listening to other people's opinions with empathy, flexible thinking, metacognition thinking, trying to work carefully and precisely, asking and posing problems effectively, using old experiences to form new knowledge, thinking and communicating clearly, using the senses in collecting and processing data, creating, fantasizing, and innovating, enthusiastic and responding, daring to be responsible and face risks, humorous, interdependent thinking, and continuous learning. Indicators of creativity are a broad and deep curiosity, having imagination. having initiative, openness to new experiences, ability to ask good questions, having original ideas, ability to see problems from various points of view, flexibility in thinking, freedom of expression.

Data analysis in this research use multiple regression test. But before the regression test done, the data have to be multicollinearity, heteroscedasticity, and normality. Data analysis in this study use SPSS 16 software.

\section{RESULT AND DISCUSSION}

Based on data using SPSS 16 obtained the following results in Table 1-3. 
DOI: https://doi.org/10.24127/ajpm.v9i1.2589

Tabel 1. Model Summary ${ }^{\mathrm{b}}$

\begin{tabular}{llllll}
\hline Model & $\mathbf{R}$ & R Square & Adjusted R Square & $\begin{array}{l}\text { Std. Error of the } \\
\text { Estimate }\end{array}$ & $\begin{array}{l}\text { Durbin- } \\
\text { Watson }\end{array}$ \\
\hline 1 & $.764^{\mathrm{a}} .584$ & .541 & 16.10050 & 1.950 \\
\hline
\end{tabular}

a. Predictors: (Constant), self regulated learning, habit of mind, and creativity

b. Dependent Variable: HOTS

Table 2. ANOVA

\begin{tabular}{lllllll}
\hline Model & Sum of Squares & df & Mean Square & F & Sig. \\
\hline 1 & Regression & 10549.865 & 3 & $\mid 3516.622$ & 13.566 & $.000^{\mathrm{a}}$ \\
& Residual & 7517.560 & 29 & 259.226 & & \\
$\quad$ Total & 18067.424 & 32 & & & \\
\hline
\end{tabular}

a. Predictors: (Constant), self regulated learning, habit of mind, and creativity

b. Dependent Variable: HOTS

Table 3. Coefficients ${ }^{\mathrm{a}}$

\begin{tabular}{|c|c|c|c|c|c|c|c|c|}
\hline \multirow{2}{*}{\multicolumn{2}{|c|}{ Model }} & \multicolumn{2}{|c|}{$\begin{array}{l}\text { Unstandardized } \\
\text { Coefficients }\end{array}$} & \multirow{2}{*}{$\begin{array}{c}\begin{array}{c}\text { Standardized } \\
\text { Coefficients }\end{array} \\
\text { Beta }\end{array}$} & \multirow[t]{2}{*}{$\mathbf{t}$} & \multirow[t]{2}{*}{ Sig. } & \multicolumn{2}{|l|}{$\begin{array}{c}\text { Collinearity } \\
\text { Statistics }\end{array}$} \\
\hline & & B & Std. Error & & & & Tolerance & VIF \\
\hline \multirow[t]{4}{*}{1} & (Constant) & -107.73 & 26.62 & & -4.047 & .000 & & \\
\hline & $\begin{array}{l}\text { Self regulated } \\
\text { learning }\end{array}$ & .731 & .352 & .288 & 2.077 & .047 & .744 & 1.344 \\
\hline & habit of mind & .822 & .360 & .335 & 2.285 & .030 & .669 & 1.494 \\
\hline & creativity & .742 & .297 & .343 & 2.495 & .019 & .759 & 1.317 \\
\hline
\end{tabular}

a. Dependent Variable: HOTS

Before testing multiple linear regression, it is necessary to prerequisite multiple linear regression test. The prerequisites that must be met in multiple linear regression tests are multicollinearity, autocorrelation, heteroscedasticity, and normality. In this study, the prerequisite test conducted is to all of these prerequisites except autocorrelation. The autocorrelation prerequisite is performed when the data used to estimate the linear regression model is the time series data so that the required assumption test is free from autocorrelation.
In Table 3, it is found that VIF value for the self regulated learning variable is 1,344 , habit of mind is 1.494 , and creativity is 1.317 . The three VIF values are less than 10 . Thus it can be concluded that independent variables are free from multicollinearity problems, so the assumption of multicollinearity in this study has been met. 
Normal P-P Plot of Regression Standardized Residual

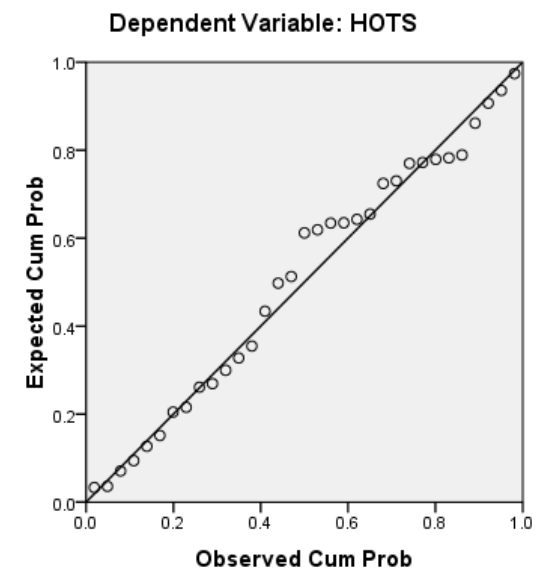

Figure 1. Normalitas P-P Plot.

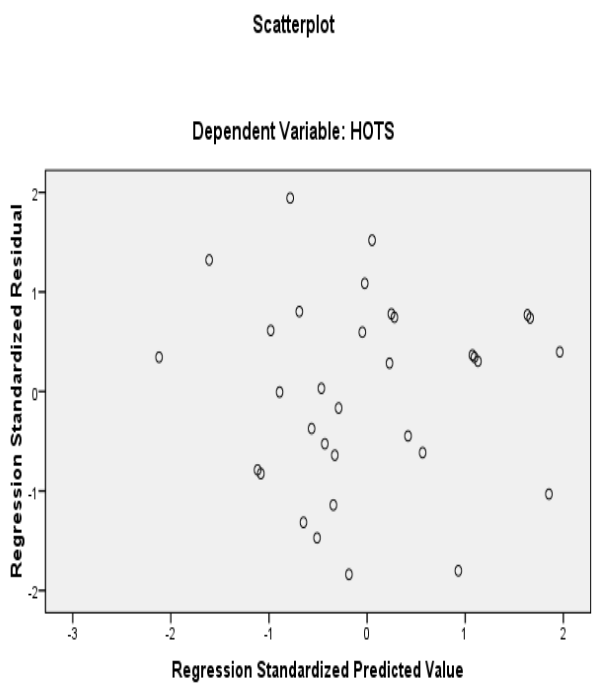

Figure 2. Heteroskedastisitas.

Heteroskedasticity testing can be done by making Scatterplot (flow spread) between residual and predictor values of standardized dependent variable. Heteroskedastisitas test result can be seen in Figure 2. When seen in Figure 2, the distribution of the dots don't form a particular pattern or rule so it can be concluded there isn't heteroskedastisitas or homoskedastisitas occur. Therefore, the assumption of heteroscedasticity as a prerequisite of multiple regression tests in this study has been met.

Normality test in this study can be seen in Figure 1. Criteria of a normality data residual or not can be done with Approach Normal PP Plot by looking at the distribution of points in Figure 1. When considered from Figure 1, the points in figure 1 are relatively close to the line so it can be concluded that the data is normal distribution.

In Table 1, showed that the correlation of creativity, self regulated learning, and habit of mind to HOTS are 0.764 with a coefficient of determination of 0.541 (Adjusted $\mathrm{R}$ Square). Thus it can be stated that HOTS variation can be influenced by creativity, self regulated learning, and habit of mind of $54.10 \%$ while the rest is influenced by other factors. Based on Table 3 obtained the model of regression equation as follows:

$$
\begin{aligned}
& Y=-107,729+0,731 X_{1}+0,822 X_{2}+ \\
& 0,742 \mathrm{X}_{3}
\end{aligned}
$$

where $\mathrm{Y}$ is HOTS, $\mathrm{X}_{1}$ self regulated learning, $\mathrm{X}_{2}$ habit of mind, and $\mathrm{X}_{3}$ creativity.

Regression equation model that has been obtained need to be tested feasibility model or model reliability. To find out whether the regeneration equation model is feasible or not feasible by $\mathrm{F}$ test. If it is feasible, it can be used to explain the effect of the independent variables on the dependent variable. The results of the $\mathrm{F}$ test related to the feasibility of the model can be seen in Table 2. In Table 2 gotten prob. $F$ (SPSS results shown in the sig. Column) of 0.000 smaller than 0.05 , it can be concluded that the regression equation model is estimated to be feasible. Thus, the model of regression equations estimated is feasible to be 
used to explain the effect of self regulated learning, habit of mind, and creativity on the dependent variable of HOTS. In addition, these results also show that the effect of self regulated learning, habits of mind, and creativity simultaneously proved to influence significant HOTS or self regulated learning, habit of mind, and creativity can simultaneously be a predictor of HOTS. This result is in accordance with the opinion expalained by Hendrian, et al. (2017) that soft skills are skills possessed by students and affect the learning outcomes (HOTS). The self regulated learning, habit of mind, and creativity have different indicators but these three variables help each other in developing and enhancing student's HOTS abilities. So, students having self regulated learning, habit of mind and high creativity will certainly have a high willingness in solving problems, especially HOTS questions, able to solve problems that may not be solved by other students, and have many ideas in solve the problem given to them.

To know partial model test results or to test whether the parameters (regression coefficients and constants) expected to estimate the multiple linear regression model is the right parameter or not. The results of this test are said to be partial because in this test can be seen in partial influence of each independent variable to the dependent variable. In Table 3, it is found that prob. $t$ value of self regulated learning variable is 0.047 smaller than 0.05 so that independent variables of self regulated learning significantly influences HOTS dependent variable at alpha $5 \%$. The results of this study are in accordance with the findings and opinions of Hendrian, et al. (2017), Venty, Budiyono \& Slamet (2016), Vrieling, Bastiaens, \& Stijnen (2012), and Fadlelmula, Cakiroglu, \& Sungur (2015) explaining that self regulated learning can affect students cognitive (HOTS). One of the stages in self regulated learning is performance control. In the performance control stage includes self-control and selfmonitoring of cognitive, motivational, and behavioral strategies (Marchis, 2011). Therefore, students who has good self regulated will certainly analyze, choose appropriate strategies and evaluate the results obtained. In addition, students having good self regulated, they don't wait for others in solving the problem and accustome to solving the problem it self.

In Table 3, $t$ test also is obtained by prob $t$ values. Prob t value of habit of mind is 0.030 is smaller than 0.05 so that the independent variable of habit of mind significantly influence the dependent variable of HOTS at alpha $5 \%$. The results of this study are in accordance with the findings and opinions of Hendrian, et al. (2017) that habit of mind affects the high order thingking skills of students. One of the indicator of habit of mind is flexible thinking, metacognition thinking, thinking and communicating clearly, asking and posing problems effectively, and using old experiences to form new knowledge (Elyousif \& Abdelhamied, 2013). Therefore, students who has good habit of mind will be easy in solving the problem of HOTS because they are accustomed to solve, communicate, prove, and analyze an argument that he submitted. The results of this study indicate that it can be predictor of student HOTS. The habit of mind is needed in mathematical reasoning, problem solving, connections and communication (Elyousif \& Abdelhamied, 2013). 
The prob. $t$ value of creativity variable is 0.019 smaller than 0.05 so that independent variable of creativity significantly affects the independent variable of HOTS at alpha $5 \%$. This result is in accordance with the findings of Naderi \& Abdullah (2010) and Hodiyanto et al. (2016). Creative students certainly have many ideas and solutions proposed. The better the creativity of a person then the ideas or solutions provided more diverse and have an orginalty that is not usually done by others. Therefore, it is very rational if creativity contributes to HOTS. The results of this study also prove that creativity can be used as predictor of HOTS of students.

The results of this study indicate that soft skills (the self regulated learning, the habit of mind, and creativity) must be considered in the learning process, especially in increasing HOTS of students. In addition, the learning model that will be applied by teachers and lecturers must certainly optimize and consider soft skills. The better the soft skills of students, the higher the student HOTS will increase. Therefore, it is important to optimize the soft skills of students to increase student HOTS.

\section{CONCLUSION AND SUGGESTION}

Based on the results of research, discussion, and theoretical study then in this study can be concluded as follows: the self regulated learning, the habit of mind, and creativity separately and simultaneously can be predictor of HOTS. The results of this study can be continued by further investigators by looking at and reviewing other soft skills that can affect HOTS of students. The results of this study also indicate that the influence of HOTS is not only the model or learning strategy used but there are other variables that can affect the HOTS of students, especially the variables of self regulated learning, habit of mind, and creativity. Variables of soft skills: the variables of self regulated learning, habits of mind, and creativity should be considered for the learning outcomes of HOTS in the process of learning. In addition, teachers and lecturers must optimize soft skills to develop HOTS students.

\section{REFERENCES}

Abdullah, A. H., Abidin, N. L., \& Ali, M. (2015). Analysis of Students' Errors in Solving Higher Order Thinking Skills (HOTS) Problems for the Topic of Fraction. Asian Social Science, 11(21), 133-142.

Elyousif, Y. A. K., \& Abdelhamied, N. E. (2013). Assessing secondary school teachers' performance in developing habits of mind for the students. International

Interdisciplinary Journal of Education, 1(1032), 1-13.

Fadlelmula, F. K. (2010). Mathematical Problem Solving and SelfRegulated

Learning. International Journal of Learning, 17(3), 363-372.

Fadlelmula, F. K., Cakiroglu, E., \& Sungur, S. (2015). Developing a structural model on the relationship among motivational beliefs, self-regulated learning strategies, and achievement in mathematics. International

journal of science and
mathematics education, 13(6),
1355-1375.

Hendrian, Rohaeti, \& Sumarmo (2017). Hard Skills and Soft Skills of Student Mathematics. Bandung: PT Refika Aditama. 
Hodiyanto, H., Budiyono, B., \& Slamet, I. (2016). Eksperimentasi model pembelajaran problem posing dan problem solving dengan pendekatan pmr terhadap prestasi belajar dan kemampuan komunikasi matematis ditinjau dari kreativitas siswa kelas VII SMP Negeri di Kabupaten Sukoharjo. Jurnal Pembelajaran Matematika, 4(2), 199-214.

Hodiyanto, H. (2017a). Kemampuan Komunikasi Matematis Dalam Pembelajaran

Matematika. AdMath Edu: Jurnal Ilmiah Pendidikan Matematika, Ilmu Matematika dan Matematika Terapan, 7(1), 9-18.

Hodiyanto, H. (2017b). Pengaruh model pembelajaran problem solving terhadap kemampuan komunikasi matematis ditinjau dari gender. Jurnal Riset Pendidikan Matematika, 4(2), 219-228.

Lambertus, Bey, Anggo, Fahinu, Sudia, \& Kadir. (2014). Developing Skills Resolution mathematical Primary School Students. International Journal of Education and Research, 2(10), 601-614.

Lomibao, L. S., Luna, C. A. \& Namoco, R. A. (2016). The influence of mathematical communication on students' mathematics performance and anxiety. American Journal of Educational Research, 4 (5), 378-382.

Marchis, I. (2011). How Mathematics Teachers Develop Their Pupils' Self-Regulated Learning Skills. Acta Didactica Napocensia, 4, 9-14.

Muqodas, I. (2015). Mengembangkan Kreativitas Siswa Sekolah Dasar. Metodik Didaktik: Jurnal Pendidikan Ke-SD-an, 9(2).
Naderi, H. \& Abdullah, R. (2010). Creativity as a predictor of intelligence among undergraduate students. The Journal of American Science, 6(2), 189-194.

Novilita, H., \& Suharnan, S. (2013). Konsep diri adversity quotient dan kemandirian belajar siswa. Jurnal Psikologi Tabularasa, 8(1).

Polya, G. (1973). How To Solve It, A New Aspect of Mathematical Method. Princeton University Press: United States of Amerca.

Pawiro, Y. P., Budiyono, B., \& Slamet, I. (2015). Eksperimentasi Model Pembelajaran Problem Based Learning Dan Model Discovery Learning Serta Model Think Pair Share Materi Kubus Dan Balok Ditinjau Dari Kategori Kecerdasan Emosional Pada Kemampuan Berpikir Matematis Tingkat Tinggi Peserta Didik SMP. Journal of Mathematics and Mathematics Education, 5(1), 5160.

Pearce, D. L., Bruun, F., Skinner, K., \& Lopez-Mohler, C. (2013). What teachers say about student difficulties solving mathematical word problems in grades 25. International Electronic Journal of Mathematics Education, 8(1), 3-19.

Prayitno, S., Suwarsono, S., \& Siswono, T. (2013). Identifikasi indikator kemampuan komunikasi matematis siswa dalam menyelesaikan soal matematika berjenjang pada tiap-tiap jenjangnya. Prosiding Konferensi Nasional Pendidikan Matematika $V$, 384-389.

Salemeh, Z., \& Etchells, M. J. (2016). A Case Study: Sources of Difficulties in Solving Word Problems in an International 
DOI: https://doi.org/10.24127/ajpm.v9i1.2589

Private School. Electronic

International Journal of

Education, Arts, and Science (EIJEAS), 2, 149-163.

Venty, M., Budiyono, B., \& Slamet, I. (2016). Eksperimentasi Model Pembelajaran Kooperatif Tipe Team Assisted Individualization (Tai), Group Investigation (Gi), Dan Pembelajaran Langsung Pada Materi Persamaan Garis Lurus Ditinjau Dari Kemandirian Belajar Siswa Kelas Viii Smp Negeri Se-Kota Surakarta Tahun Pelajaran 2015/2016. Journal of Mathematics and Mathematics Education, 6(1), 47-56.

Vrieling, E. M., Bastiaens, T. J., \& Stijnen, S. (2012). Effects of increased self-regulated learning opportunities on student teachers' metacognitive and motivational development. Interna-tional journal of educational research, 53, 251-263.

Yu, K. C., Fan, S. C., \& Lin, K. Y. (2015). Enhancing Students' problem-Solving Skills Through Context-Based Learning. International Journal of Science and Education, 13(6), 1377-1401. 